\title{
Generation of ATP during Cytochrome-linked Anaerobic Electron Transport in Propionic Acid Bacteria
}

\author{
By WYTSKE DE VRIES, WILLEMINA M. C. VAN WYCK-KAPTEYN \\ AND A. H. STOUTHAMER \\ Microbiology Department, Biological Laboratory, Free University, \\ De Boelelaan I087, Amsterdam, The Netherlands
}

(Received 30 October 1972)

\begin{abstract}
SUMMARY
Enzyme determinations in bacteria-free extracts and dual-wavelength experiments with membrane suspensions established that Propionibacterium freudenreichii converted glycerol into triose phosphate via glycerol kinase and NAD-independent glycerol I-phosphate dehydrogenase which is closely linked to cytochrome $b$. Glycerol I-phosphate dehydrogenase uses fumarate as a final hydrogen acceptor. The enzyme system catalysing fumarate reduction with glycerol I-phosphate as a hydrogen donor, is membrane bound and is strongly inhibited by $2-n$-heptyl-4-hydroxyquinoline-N-oxide (HOQNO). Fumarate reduction with reduced benzyl-viologen is not inhibited by HOQNO. Cytochrome $b$ is therefore probably involved in the anaerobic electron transport from glycerol I-phosphate to fumarate. Molar growth yields and fermentation balances were determined for $P$. freudenreichii and $P$. pentosaceum growing on glucose, fructose, glycerol and lactate and ATP yields ( $\mathrm{mol}$ of ATP formed/mol of substrate fermented) were calculated assuming that I mol ATP is formed in the electron transport from glycerol I-phosphate and lactate to fumarate, and that 2 mol ATP are formed in the electron transport from NADH to fumarate. Mean $Y^{A T P}$ values (g dry wt bacteria/mol ATP) were 15.2 and 12.9 for $P$. freudenreichii, and I 6.4 and II $\cdot 8$ for $P$. pentosaceum each growing on complex or synthetic medium respectively. The observation that for each strain $Y^{\mathrm{ATP}}$ values were constant for the same medium, supported our assumptions on energy generation in propionic acid bacteria.
\end{abstract}

\section{INTRODUCTION}

De Vries, van Wyck-Kapteyn \& Stouthamer (I972) reported the presence of cytochrome $b$, cytochrome $a$ or $a_{1}$, cytochrome $a_{2}$ and a carbon monoxide-binding pigment in propionic acid bacteria and that propionic acid bacteria obtained energy by oxidative phosphorylation. The lactate dehydrogenase of Propionibacterium freudenreichii was not linked to NAD but from reduced minus oxidized difference spectra of intact bacteria and from experiments with 2-n-heptyl-4-hydroxy-quinoline-N-oxide (HOQNO), an inhibitor of cytochrome $b$ function (Cox et al. 1970), they concluded that cytochrome $b$ functioned in anaerobic electron transport from lactate to fumarate. Recently Sone (1972) described a membranebound cytochrome $b$-linked electron transfer system in P. arabinosum which oxidized NADH, glycerol I-phosphate and lactate with fumarate as a hydrogen acceptor.

In the present investigation we have studied the catabolism of glycerol and lactate by propionic acid bacteria in more detail, and by measuring the molar growth yields of bacteria growing on glucose, fructose, glycerol or lactate the presence of energy-yielding anaerobic electron transport systems can be deduced. 


\section{METHODS}

Growth experiments. The experiments were done with Propionibacterium freudenreichii and $P$. pentosaceum (de Vries et al. 1972). Growth yields were measured in complex medium (de Vries et al. 1972) and in synthetic medium. The synthetic medium contained (per 1 distilled water): casein hydrolysate (Oxoid), $5 \mathrm{~g} ;\left(\mathrm{NH}_{4}\right)_{2} \mathrm{SO}_{4}, \mathrm{I} \cdot 5 \mathrm{~g} ; \mathrm{KH}_{2} \mathrm{PO}_{4}, 3 \cdot 0 \mathrm{~g}$; $\mathrm{Na}_{2} \mathrm{HPO}_{4}, 2.6 \mathrm{~g}$; tryptophan, $\mathrm{O} \cdot \mathrm{I} \mathrm{g}$; adenine, guanine, uracil and xanthine, each $5 \mathrm{mg}$; $\mathrm{MgSO}_{4} \cdot 7 \mathrm{H}_{2} \mathrm{O}, 0.16 \mathrm{~g} ; \mathrm{MnSO}_{4} \cdot 4 \mathrm{H}_{2} \mathrm{O}, 3 \mathrm{mg} ; \mathrm{Co}\left(\mathrm{NO}_{3}\right)_{2}$, Io mg; $\mathrm{FeSO}_{4} \cdot 7 \mathrm{H}_{2} \mathrm{O}, 8 \mathrm{mg}$; biotin, $0.7 \mathrm{mg}$; thiamin, I $\mathrm{mg}$; riboflavin, I $\mathrm{mg}$; pyridoxin, $2 \mathrm{mg}$; Ca pantothenate, I $\mathrm{mg}$; nicotinic acid, I mg; $p$-amino benzoic acid, $0 . \mathrm{I} \mathrm{mg}$; $\mathrm{pH} 6.5$. For growth experiments with glycerol the synthetic medium described by Bauchop \& Elsden (I960) was used. Growthlimiting concentrations of glucose or fructose (up to $5 \mu \mathrm{mol} / \mathrm{ml}$ ), sodium lactate (up to $30 \mu \mathrm{mol} / \mathrm{ml}$ ), or glycerol (up to $10 \mu \mathrm{mol} / \mathrm{ml}$ ) were added to the media. Glucose and fructose were sterilized by filtration. Sodium DL-lactate solution containing $63 \%$ L-lactate and $7 \%$ D-lactate was obtained from British Drug Houses Ltd, Poole, Dorset. Both substrates were used by propionic acid bacteria. Cultures were grown at $30{ }^{\circ} \mathrm{C}$ under nitrogen $(99.9 \%$ pure). Growth yields on lactate were measured in the Microferm Laboratory Fermentor (Model MF I02, New Brunswick, New Jersey, U.S.A.) without pH control. Cultures on glucose or glycerol were grown in a Chemap 2 1-Vibro-glass-fermentor (Chemap AG, Männedorf $\mathrm{ZH}$, Switzerland) with the $\mathrm{pH}$ maintained at 6.5 with an Electrofact $\mathrm{pH}$ meter (type 36000) and an alarm-unit type 42800 (Electrofact N.V., Amersfoort, The Netherlands). Growth of cultures was followed turbidimetrically at $660 \mathrm{~nm}$. When maximum growth had been attained, growth yields were measured by filtration on membrane filters (de Vries \& Stouthamer, 1968). Propionate, succinate, pyruvate and acetate were determined in supernatant fluids (de Vries et al. 1972). In the determination of molar growth yields and fermentation balances corrections were made for growth and fermentation products formed in the absence of an added energy source. Total polysaccharide in whole cells was measured with the anthrone reagent (Trevelyan \& Harrison, 1952) using glucose as a standard.

Measurement of enzyme activities. Bacterial extracts were prepared as described previously (de Vries et al. 1972). A crude membrane fraction was obtained by centrifuging bacteriafree extracts at $\mathrm{I} 40000 \mathrm{~g}$ for $75 \mathrm{~min}$, and resuspending the pellet in $0.04 \mathrm{M}$-potassium phosphate buffer ( $\mathrm{pH} 7 \cdot 0$ ) containing $0.005 \mathrm{M}-\mathrm{MgCl}_{2}$. Protein was measured by the method of Lowry, Rosebrough, Farr \& Randall (I95I) using bovine serum albumin as a standard. NAD-dependent glycerol dehydrogenase and glycerol I-phosphate dehydrogenase were measured with a Unicam SP 820 constant wavelength scanner (Unicam Instruments Ltd, Cambridge) at $340 \mathrm{~nm}$, in an assay mixture $(2.6 \mathrm{ml})$ containing: tris buffer ( $\mathrm{pH} 7.4), 35 \mathrm{~mm}$; glycerol or sodium glycerol I-phosphate, $2 \mathrm{mM}$; NAD, $0.8 \mathrm{~mm}$; bacterial extract, 0.2 to $0.4 \mathrm{mg}$ protein $/ \mathrm{ml}$ assay mixture. Lactate dehydrogenase, glycerol dehydrogenase, glycerol I-phosphate dehydrogenase and malate dehydrogenase were measured spectrophotometrically at $600 \mathrm{~nm}$ with 2,6-dichlorophenol indophenol (2,6-DCIP) as a $\mathrm{H}$-acceptor in an assay mixture $(3.0 \mathrm{ml})$ containing: sodium potassium phosphate buffer $(\mathrm{pH} 6.8), 25 \mathrm{~mm}$; sodium DL-lactate, $15 \mathrm{mM}$, or glycerol, $3 \mathrm{mM}$, or glycerol I-phosphate, $6 \mathrm{mM}$, or sodium DLmalate, Io mM; ethylene diamine tetraacetic acid, I. $6 \mathrm{~mm}$; 2,6-DCIP, 0.05 mM; bacterial extract, $0 . \mathrm{I}$ to $0.3 \mathrm{mg}$ protein $/ \mathrm{ml}$ assay mixture. Glycerol I-phosphate-fumarate dismutation was measured by the amount of succinate formed under nitrogen in a Thunberg tube at $25^{\circ} \mathrm{C}$. The system $(2 \mathrm{ml})$ contained: potassium phosphate buffer $(\mathrm{pH} 7 \cdot 0), 30 \mathrm{mM} ; \mathrm{MgCl}_{2}$, $3 \mathrm{~mm}$; glycerol I-phosphate, I5 mM; sodium fumarate, $20 \mathrm{~mm}$; bacterial extract or mem- 
Table I. Specific activities of dehydrogenases in extracts of Propionibacterium freudenreichii involved in the metabolism of lactate and glycerol

Hydrogen donor

Lactate
Lactate
Lactate
Glycerol
Glycerol
Glycerol I-phosphate
Glycerol I-phosphate
Glycerol I-phosphate
Malate
Malate
NADH

$\begin{array}{lc}\text { Hydrogen acceptor } & \text { Specific activity* } \\ \text { NAD } \dagger & 0.0 \\ \text { 2,6-DCIP } & 0.9 \text { I } \\ \text { Fumarate } \dagger & 0.07 \\ \text { NAD } & 0.0 \\ \text { 2,6-DCIP } & 0.0 \\ \text { NAD } & 0.0 \\ \text { 2,6-DCIP } & 0.36 \\ \text { Fumarate } & 0.14 \\ \text { 2,6-DCIP } & 0.0 \\ \text { Pyruvate } & 0.0 \\ \text { Oxaloacetate } & 27.2\end{array}$

* Specific activity expressed as $\mu \mathrm{mol}$ hydrogen acceptor reduced $/ \mathrm{mg}$ protein $/ \mathrm{min}$ or $\mu$ mol hydrogen donor oxidized/mg protein/min.

$\dagger$ See de Vries et al. (1972).

brane suspension, $0.5 \mathrm{mg}$ protein $/ \mathrm{ml}$ assay mixture. For the determination of fumarate hydratase (fumarase), glycerol I-phosphate was omitted from the reaction mixture. After $20 \mathrm{~min}$, the reaction was stopped with $0.8 \mathrm{ml} \mathrm{I} 8 \mathrm{~N}-\mathrm{H}_{2} \mathrm{SO}_{4}$. After centrifuging succinate and fumarate were measured in the supernatant fluid with the gas chromatograph as described by Holdeman \& Moore (I972). Fumarate reduction with reduced benzylviologen as a hydrogen donor, was measured manometrically by following the hydrogen uptake in Warburg vessels as described by Pichinoty \& Piéchaud (I968) for nitrate reductase. The assay of glycerol kinase was carried out spectrophotometrically by determination of glycerol I-phosphate with glycerol I-phosphate dehydrogenase (Boehringer \& Soehne, GmbH, Mannheim, Germany) and NAD (Kennedy, I962). Malate dehydrogenase was measured spectrophotometrically at $340 \mathrm{~nm}$ in a reaction mixture $(3.0 \mathrm{ml})$ containing: tris buffer $(\mathrm{pH} 7 \cdot 4), 35 \mathrm{~mm}$; NADH, $0.2 \mathrm{~mm}$; oxaloacetate, $\mathrm{I} \cdot 7 \mathrm{~mm}$; bacterial extract, $0.002 \mathrm{mg}$ protein $/ \mathrm{ml}$ assay mixture. Malate-lactate transhydrogenase was measured spectrophotometrically with pyruvate and malate as substrates as described by Allen (1969).

Measurement of difference spectra and reduction kinetics of cytochrome $b$. Reduced minus oxidized difference spectra were recorded in an Aminco Chance spectrophotometer (American Instrument Co. Inc., Washington, U.S.A.). The reduction of cytochrome $b$ by membrane suspensions was followed with the Aminco Chance spectrophotometer set in dual-wavelength position ( 560 and $578 \mathrm{~nm}$ ) and a slide wire of full-scale deflexion 0.05 extinction units. To $3 \mathrm{ml}$ of a membrane suspension (about $2 \mathrm{mg}$ protein/ml), oxidized with air, was added either $50 \mu \mathrm{l}$ of $2 \mathrm{M}$-L-lactate, D-lactate, glycerol or glycerol I-phosphate or $\mathrm{I} 00 \mu \mathrm{l}$ of $0.8 \mathrm{M}$-fumarate.

\section{RESULTS}

Enzyme determinations in bacterial extracts and difference spectra of Propionibacterium freudenreichii. Propionibacterium freudenreichii converted glycerol to triose phosphate via glycerol kinase (sp.act. $0.06 \mu \mathrm{mol}$ NADH formed $/ \mathrm{mg}$ protein $/ \mathrm{min}$ ) and glycerol I -phosphate dehydrogenase (Table I). As with lactate dehydrogenase, glycerol I-phosphate dehydrogenase was not linked to NAD. Both enzymes used 2,6-dichlorophenol indophenol (2,6-DCIP) or fumarate as a hydrogen acceptor (Table I). Malate-lactate transhydrogenase was absent from $P$. freudenreichii. The bacterium contained a very active NAD-dependent malate dehydrogenase (Table I). 


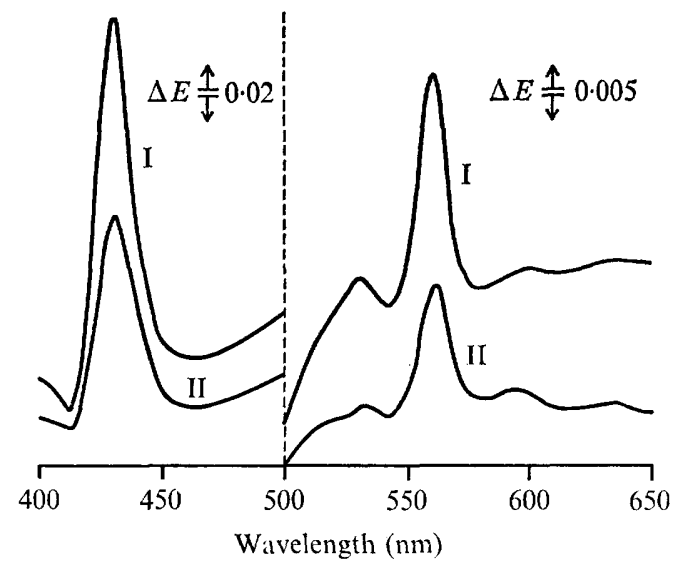

Fig. I. Reduction and re-oxidation of cytochromes in Propionibacterium freudenreichii with glycerol I-phosphate and fumarate respectively. I, glycerol I-phosphate-reduced minus oxygenoxidized difference spectrum; II, difference spectrum after addition of fumarate to the glycerol I-phosphate-reduced cell homogenate of I. The homogenate was obtained from a suspension containing about $5 \mathrm{mg}$ dry wt bacteria/ml.

Table 2 . The effect of inhibitors on fumarate reduction with glycerol $\mathrm{I}$-phosphate or reduced benzylviologen $\left(\mathrm{BVH}_{2}\right)$ by crude membrane suspensions of Propionibacterium freudenreichii

Hydrogen donor

Glycerol r-phosphate Glycerol I-phosphate Glycerol I-phosphate Glycerol I-phosphate Glycerol I-phosphate Glycerol I-phosphate $\mathrm{BVH}_{2}$ $\mathrm{BVH}_{2}$

Inhibitor
HOQNO
HOQNO
HOQNO
HOQNO
Amytal
Antimycin A
HOQNO
HOQNO

Concentration (mM) nhibition

0.025

0.01

0.005

0.0025

$2 \cdot 0$

$0 \cdot 1$

0.01 0.005

$\begin{array}{lr}(\mathrm{mM}) & (\%) \\ 0.025 & 100 \\ 0.01 & 94 \\ 0.005 & 76 \\ 0.0025 & 58 \\ 2.0 & 5 \\ 0.1 & 24 \\ 0.01 & 0 \\ 0.005 & 0\end{array}$

Propionibacterium freudenreichii contained cytochrome $b$, cytochrome $a$ or $a_{1}$, and cytochrome $a_{2}$ after growth on glycerol (Fig. I). Addition of fumarate to cell homogenates, reduced with glycerol I-phosphate, resulted in partial oxidation of cytochrome $b$ (Fig. I). Similar spectra were found previously with lactate as a reducing substrate (de Vries et al. 1972).

The effect of inhibitors on enzyme activities and reduction kinetics of cytochrome $b$ in membrane fractions. Differential centrifugation showed that the enzyme system catalysing the electron transfer from glycerol I-phosphate to fumarate was membrane bound. The specific activity of the system in the membrane fraction was $0.24 \mu \mathrm{mol}$ succinate formed $/ \mathrm{mg}$ protein/min. The specific activity of fumarate reductase with reduced benzylviologen as a hydrogen donor was $0.49 \mu \mathrm{mol}$ hydrogen taken up $/ \mathrm{mg}$ protein $/ \mathrm{min}$. The electron transfer from glycerol I-phosphate to fumarate was only slightly inhibited by amytal and antimycin A (Table 2), and was extremely sensitive to 2-n-heptyl-4-hydroxyquinoline-N-oxide (HOQNO), a known inhibitor of cytochrome $b$ function (Cox et al. 1970). De Vries et al. (I972) reported that lactate-fumarate dismutase is inhibited by $0.05 \mathrm{mM}-\mathrm{HOQNO}$ for $85 \%$. Fumarate reductase, with reduced benzylviologen as a hydrogen donor $\left(\mathrm{BVH}_{2}\right)$, was not inhibited at all by HOQNO (Table 2). 


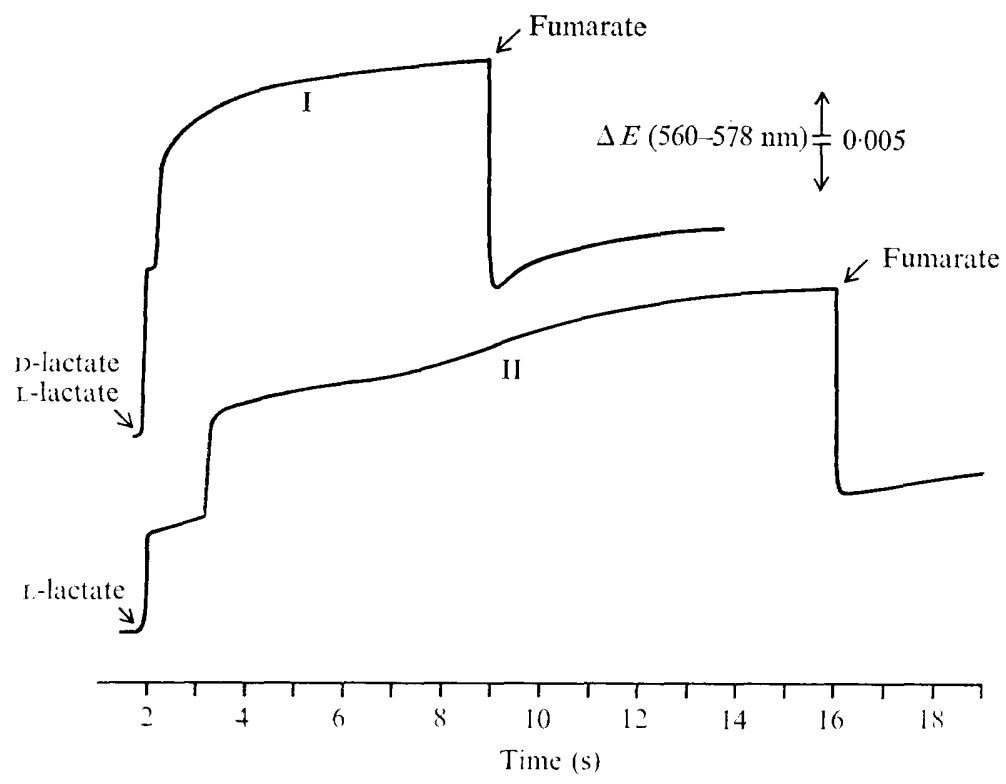

Fig. 2. Cytochrome $b$ reduction with D-lactate and L-lactate by membrane suspensions (about $2 \mathrm{mg}$ protein $/ \mathrm{ml}$ ) from lactate-grown Propionibacterium freudenreichii, in the absence (I) and presence (II) of $0.05 \mathrm{~mm}-\mathrm{HOQNO}$.

Dual-wavelength experiments (Fig. 2) show that membrane suspensions from Propionibacterium freudenreichii reduced cytochrome $b$ equally in the presence of D-lactate and L-lactate. After addition of lactate to membrane suspensions, oxidized with air, the aerobic steady state $(45 \%$ reduction of cytochrome $b)$ was attained immediately. After 30 s oxygen was exhausted from the suspension and cytochrome $b$ was reduced nearly completely (for $90 \%$ as compared with the extent of cytochrome $b$ reduction in the presence of dithionite). Fumarate oxidized cytochrome $b$ to a steady-state value of $54 \%$ reduction. In the presence of HOQNO the percentage reduction of cytochrome $b$ in the aerobic steady state was $34 \%$ and the steady state was prolonged to I $20 \mathrm{~s}$. Addition of fumarate resulted in a steady state of $46 \%$ reduction of cytochrome $b$. Experiments with limiting amounts of fumarate could not be done because of high fumarase activity in membrane suspensions. The results show that HOQNO inhibits electron transport from lactate to cytochrome $b$. Similar results were found with glycerol I-phosphate as a reducing substrate. Glycerol did not reduce cytochrome $b$. The observations are in agreement with the results of the enzyme determinations (Table I) which show that $P$. freudenreichii converts glycerol to triose phosphate via glycerol kinase and NAD-independent glycerol I-phosphate dehydrogenase.

\section{Molar growth yields and fermentation balances}

Table 3 shows molar growth yields and fermentation balances for Propionibacterium freudenreichii and P. pentosaceum. All values are the mean of two or three determinations. The differences between the individual values and the corresponding mean values varied from 4 to $8 \%$. Fermentation balances for lactate and glycerol agreed with theoretical fermentation balances (see the legends to Fig. 3 to 5). Carbon recoveries for glucose and fructose were low ( 80 to $90 \%$ ). However, traces of pyruvate and succinate were sometimes 
Table 3. Molar growth yields and fermentation balances of Propionibacterium freudenreichii and P. pentosaceum

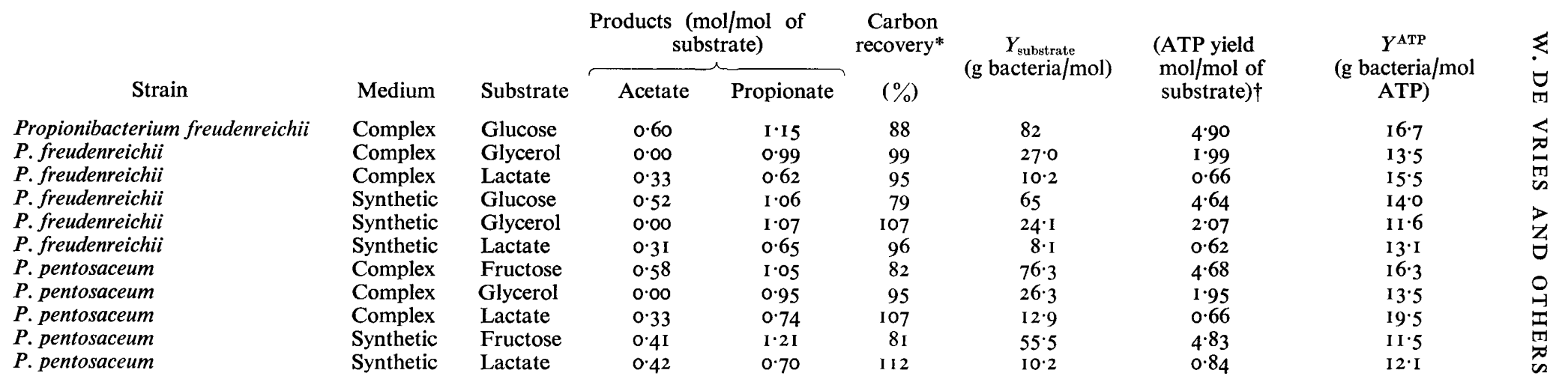

* For the calculation of carbon recoveries the amount of $\mathrm{CO}_{2}$ formed was estimated from the amount of acetate formed. $\dagger$ See Discussion. 


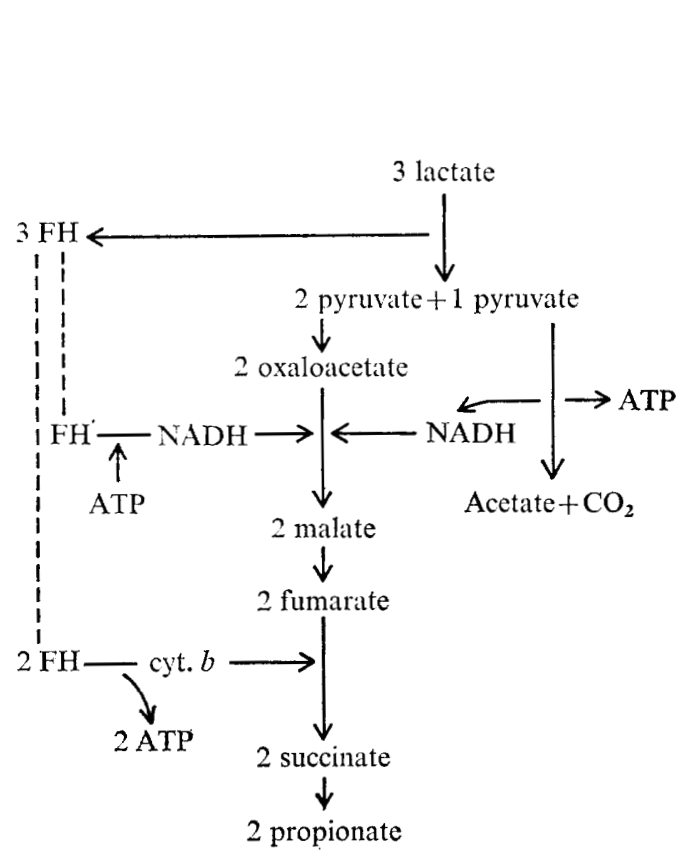

Fig. 3

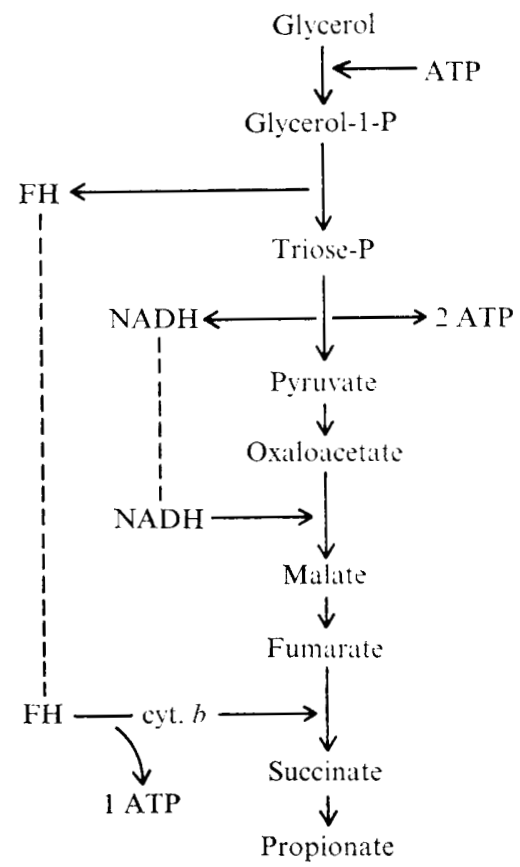

Fig. 4

Fig. 3. Simplified fermentation system and postulated scheme for ATP formation during lactate fermentation by propionic acid bacteria: lactate $\longrightarrow 0.33$ acetate $+0.33 \mathrm{CO}_{2}+0.67$ propionate +0.67 ATP. (FH $=$ reduced flavoprotein.)

Fig. 4. Simplified fermentation system and postulated scheme for ATP formation during glycerol fermentation by propionic acid bacteria: glycerol $\longrightarrow$ propionate +2 ATP $(\mathrm{FH}=$ reduced flavoprotein).

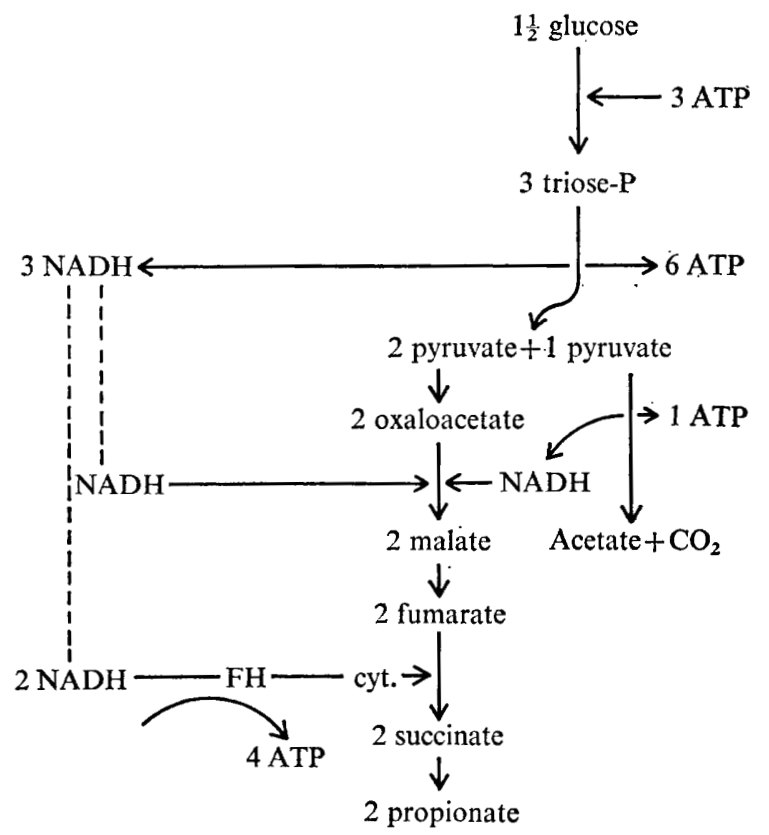

Fig. 5. Simplified fermentation system and postulated scheme for ATP formation during glucose fermentation by propionic acid bacteria: glucose $\longrightarrow 0.67$ acetate $+0.67 \mathrm{CO}_{2}+\mathrm{I} \cdot 33$ propionate $+5 \cdot 33 \mathrm{ATP}(\mathrm{FH}=$ reduced flavoprotein $)$. 
found. Growth yields on hexoses were very high (up to $82 \mathrm{~g}$ dry wt bacteria/mol glucose). The total polysaccharide content of $P$. freudenreichii varied from 12 to $14 \%$, the normal percentage for cell wall polysaccharides (Gunsalus \& Shuster, 196I). Thus, the high molar growth yields were not due to formation of storage products.

\section{DISCUSSION}

Dual-wavelength experiments with membrane suspensions from Propionibacterium freudenreichii show that oxidation of L-lactate, D-lactate and glycerol I-phosphate is closely linked to reduction of cytochrome $b$. Fumarate oxidizes reduced cytochrome $b$. Fumarate reductase activity, with lactate or glycerol I-phosphate as a hydrogen donor, is membrane bound and is strongly inhibited by HOQNO, whereas fumarate reductase with reduced benzylviologen is not inhibited at all by HOQNO. The data indicate that cytochrome $b$ is involved in the electron transfer from lactate and glycerol I-phosphate to fumarate. As the percentage reduction of cytochrome $b$ is lower in the presence of HOQNO than in its absence, HOQNO probably inhibits the electron transport from lactate and glycerol 1phosphate before cytochrome $b$. The functioning of other cytochromes ( $a$ or $\left.a_{1}, a_{2}\right)$ and chinons present in $P$. freudenreichii (unpublished results) remains to be resolved. Sone (1972) demonstrated flavoprotein, non-haeme iron, phospholipids and cytochrome $b$ in the particulate fraction of $P$. arabinosum. He suggested that these components, together with membrane-bound dehydrogenases, constitute a particular type of electron transfer system from NADH, glycerol I-phosphate and lactate to fumarate. From different effects of inhibitors he postulated a scheme of the electron transfer pathway from the three electron donors mentioned to fumarate and oxygen. He did not describe the presence of cytochrome $a$ (or $a_{1}$ ) and $a_{2}$, and a carbon monoxide-binding pigment in $P$. arabinosum. The involvement of cytochrome $b$ (or $c$ ) in the reduction of fumarate has been found in a number of other anaerobic bacteria: in species of Bacteroïdes (White, Bryant \& Caldwell, I962; Rizza, Sinclair, White \& Cuorant, 1968), in Vibrio succinogenes (Jacobs \& Wolin, 1963) and in Desulfovibrio gigas (Hatchikian \& Le Gall, I972). Kröger \& Dadak (I969) described a cytochrome $b$-linked electron transport from glycerol I-phosphate to fumarate in Bacillus megaterium.

By calculating $Y^{\text {ATP }}$ values (g dry wt bacteria/mol ATP) from molar growth yields one can see whether the anaerobic electron transport in Propionibacterium freudenreichii and $P$. pentosaceum is associated with oxidative phosphorylation. In the calculation of $Y^{\mathrm{ATP}}$ values we postulate that $I$ mol ATP is formed in the transfer of an electron pair from lactate and glycerol I-phosphate to fumarate, i.e. $P / 2 e=\mathrm{I}$. The free energy change in the electron transport from NADH to fumarate is large enough to postulate a yield of 2 mol ATP $(P / 2 e=2)$. The presence of two phosphorylation sites between NADH and cytochrome $b$ has been shown in several aerobic bacteria (Brodie \& Adelson, 1965; Ackrell \& Jones, I97I). In the fermentation of lactate we must assume energy-consuming, reversed electron transport in the conversion of oxaloacetate into malate (Fig. 3). Just as previously found by Allen, Kellermeyer, Stjernholm, \& Wood (1964) for $P$. pentosaceum, malate dehydrogenase of $P$. freudenreichii, is NAD-dependent. Lactate-malate transhydrogenase, reported by Allen (I969) to be present in Veillonella and to be absent from $P$. shermanii, was not found in $P$. freudenreichii. The calculation of the theoretical ATP yield from lactate, glycerol and glucose is shown in Fig. 3 to 5. The ATP yields given in Table 3 were calculated from the fermentation balances shown in Table 3 . In this calculation the extent of oxidative phosphorylation was deduced from the amount of propionate formed. For instance the ATP 
Table 4. $Y^{\text {ATP }}$ values calculated from molar growth yields found by Bauchop \& Elsden (1960) for Propionibacterium pentosaceum growing on synthetic medium

$\begin{array}{lccc}\text { Substrate } & \begin{array}{c}\text { Theoretical ATP yield } \\ \text { (mol/mol of substrate) }\end{array} & \begin{array}{c}Y_{\text {substrate }} \\ \text { (g bacteria/mol) }\end{array} & \begin{array}{c}Y^{\text {ATP }} \\ \text { (g bacteria/mol) }\end{array} \\ \text { Glucose } & 5.33 & 37.5 & 7 \cdot 0 \\ \text { Glycerol } & 2.0 & 20 \cdot 0 & 10 \cdot 0 \\ \text { Lactate } & 0.67 & 7 \cdot 6 & 1 \mathrm{I} \cdot 4\end{array}$

* See Fig. 3 to 5 .

yield from glucose for $P$. freudenreichii growing on complex medium, is 2 (EmbdenMeyerhof pathway) $+0 \cdot 60$ (acetate formation) $+\mathrm{I} \cdot \mathrm{I} 5 \times 2$ (propionate formation; $\mathrm{P} / 2 e=2$ ). For glycerol the ATP yield is I (Embden-Meyerhof pathway) $+0.99 \times \mathrm{I}$ (propionate formation; $\mathrm{P} / 2 e=\mathrm{I}$ ). For lactate the ATP yield is 0.33 (acetate formation) $+0.62 \times \mathrm{I}$ (propionate formation; $\mathbf{P} / 2 e=1)-(0.62-0.33)$ (reversed electron transport). As $Y^{\text {ATP }}$ values, calculated by dividing molar growth yields by ATP yields, were rather constant for each strain growing with different substrates on the same medium (Table 3), the assumptions made in the calculation of the ATP yield/mol of substrate are probably correct. Calculations which do not take into account oxidative phosphorylation during anaerobic electron transport yield very high $Y^{\mathrm{ATP}}$ values (for instance from 27.0 to $3 \mathrm{I}^{\cdot} 5$ for $P$. freudenreichii growing on complex medium). These values are even higher than the theoretical $Y^{\text {ATP }}$ value of $26 \cdot 7$ calculated by Forrest \& Walker (I97I). Our observation that the mean $Y^{\text {ATP }}$ value is higher on complex medium (I 5.2 for $P$. freudenreichii $; 16 \cdot 4$ for $P$. pentosaceum) than on synthetic medium (I2.9 for $P$. freudenreichii; II 8 for $P$. pentosaceum), is well known for other bacteria (Stouthamer, 1969).

Molar growth yields found by Bauchop \& Elsden (I960) for Propionibacterium pentosaceum are given in Table 4. Their data for glycerol and lactate, yielding constant $Y^{\mathrm{ATP}}$ values, support our assumptions on energy generation in propionic acid bacteria. However, the molar growth yield found by Bauchop \& Elsden (1960) for glucose ( $37.5 \mathrm{~g}$ dry wt bacteria/mol glucose) was much lower than our value of $65 \mathrm{~g}$ bacteria/mol glucose for $P$. freudenreichii. This difference may be due to Bauchop \& Elsden (1960) not using $\mathrm{pH}$-controlled cultures.

Our molar growth yields for propionic acid bacteria growing with glucose or glycerol did not differ very much from the values given by Hobson (1965) and Hobson \& Summers (1967) for Selenomonas ruminantium and Anaerovibrio lipolytica growing on hexoses or glycerol. Both bacteria form propionate via the succinate pathway (Joyner \& Baldwin, 1966; Hobson \& Summers, I967; Paynter \& Elsden, 1970). In a recent paper, Hobson \& Summers (1972) discussed the formation of additional ATP in the conversion of pyruvate to propionate by the selenomonad growing with glucose: one ATP could be formed in the flavoprotein-linked electron transport from NADH to fumarate as suggested previously by Bauchop \& Elsden (I960), one ATP could be formed in the conversion of pyruvate to malate by the malic enzyme and a third mole could be formed in the conversion of methylmalonyl CoA to propionate and carbon dioxide. However, the latter explanations do not apply to propionic acid bacteria which convert pyruvate to propionate via malate dehydrogenase and methylmalonyl CoA transcarboxylase (Allen et al. 1964). From the results presented in this paper we consider the formation of two moles of ATP in the cytochromelinked electron transport from NADH to fumarate the most probable explanation for the high molar growth yields of propionic acid bacteria. 


\section{REFERENCES}

ACKrell, B. A. L. \& Jones, C. W. (197I). The respiratory system of Azotobacter vinelandii. I. Properties of phosphorylating respiratory membranes. European Journal of Biochemistry 20, 22-28.

Allen, S. H. G. (I969). Malate-lactate transhydrogenase from Micrococcus lactilyticus. In Methods in Enzymology, vol. 13, pp. 262-269. Edited by S. P. Colowick and N. O. Kaplan. New York and London: Academic Press.

Allen, S. H. G., Kellermeyer, R. W., Stjernholm, R. L. \& Wood, H. G. (1964). Purification and properties of enzymes involved in the propionic acid fermentation. Journal of Bacteriology 87, 17 I-I87.

BAuChOP, T. \& ElSDEN, S. R. (1960). The growth of micro-organisms in relation to their energy supply. Journal of General Microbiology 23, 457-469.

Brodie, A. F. \& Adelson, J. W. (1965). Respiratory chains and sites of coupled phosphorylation. Science, New York 149, 265-269.

Cox, G. B., Newton, N. A., Gibson, F., Snoswell, A. M. \& Hamilton, J. A. (1970). The function of ubiquinone in Escherichia coli. Biochemical Journal $117,551-562$.

ForRest, W. W. \& WALKER, D. J. (I97I). The generation and utilization of energy during growth. In Advances in Microbial Physiology, vol. 5, pp. 21 3-274. Edited by A. H. Rose and J. F. Wilkinson. New York and London: Academic Press.

Gunsalus, I. C. \& Shuster, C. W. (1961). Energy yielding metabolism in bacteria. In The Bacteria, vol. 2, pp. 1-58. Edited by I. C. Gunsalus and R. Y. Stanier, New York and London: Academic Press.

Hatchikian, E. C. \& Le Gall, J. (1972). Evidence for the presence of a $b$-type cytochrome in the sulfatereducing bacterium Desulfovibrio gigas, and its role in the reduction of fumarate by molecular hydrogen. Biochimica et biophysica acta $\mathbf{2 6 7}, 479-484$.

Hobson, P. N. (1965). Continuous culture of some anaerobic and facultatively anaerobic rumen bacteria. Journal of General Microbiology 38, 167-180.

Hobson, P. N. \& Summers, R. (I967). The continuous culture of anaerobic bacteria. Journal of General Microbiology 47, 53-65.

Hobson, P. N. \& Summers, R. (I972). ATP pool and growth yield in Selenomonas ruminantium. Journal of General Microbiology 70, 35I-360.

Holdeman, L. V. \& Moore, W. E. C. (1972). Anaerobe Laboratory Manual. Blacksburg, Virginia, U.S.A.: Virginia Polytechnic Institute and State University.

JACOBS, N. J. \& WoLIN, M. J. (I963). Electron-transport system of Vibrio succinogenes. I. Enzymes and cytochromes of the electron-transport system. Biochimica et biophysica acta 69, 18-28.

JoYNER, A. E. \& BALDwin, R. L. (I966). Enzymatic studies of pure cultures of rumen micro-organisms. Journal of Bacteriology 92, $132 \mathrm{I}-\mathrm{I} 330$.

KenNedy, E. P. (1962). Glycerokinase. In Methods in Enzymology, vol. 5, pp. 476-479. Edited by S. P. Colowick and N. O. Kaplan. New York and London: Academic Press.

KRÖGER, A. \& DADÁK, V. (1969). On the role of quinones in bacterial electron transport. The respiratory system of Bacillus megaterium. European Journal of Biochemistry II, 328-340.

Lowry, O. H., Rosebrough, N. J., Farr, A. L. \& Randall, R. J. (I95I). Protein measurement with the Folin phenol reagent. Journal of Biological Chemistry 193, 265-275.

PAYNTER, M. J. B. \& ElSDEN, S. R. (I970). Mechanism of propionate formation by Selenomonas ruminantium. Journal of General Microbiology 6r, I-7.

Pichinoty, F. \& PiÉchaud, M. (1968). Recherche des nitrate-réductases bactériennes A et B: méthodes. Annales de l'Institute Pasteur I14, 77-98.

Rizza, V., Sinclair, P. R., White, D. C. \& Cuorant, P. R. (1968). Electron transport system of the protoheme-requiring anaerobe B. melaninogenicus. Journal of Bacteriology 96, 665-67I.

SONE, N. (1972). The redox reactions in propionic acid fermentation. I. Occurrence and nature of an electron transfer system in Propionibacterium arabinosum. Journal of Biochemistry 71, 931-940.

Stouthamer, A. H. (I969). Determination and significance of molar growth yields. In Methods in Microbiology, vol. I, pp. 629-663. Edited by J. R. Norris and D. W. Ribbons. New York and London: Academic Press.

Trevelyan, W. E. \& Harrison, J. S. (I952). Studies on yeast metabolism. I. Fractionating and microdetermination of cell carbohydrates. Biochemical Journal 5o, 298-303.

DE VRies, W. \& Stouthamer, A. H. (1968). Fermentation of glucose, lactose, galactose, mannitol and xylose by bifidobacteria. Journal of Bacteriology 96, 472-478. 
DE VRIES, W., van WyCK-Kapteyn, W. M. C. \& Stouthamer, A. H. (1972). Influence of oxygen on growth, cytochrome synthesis and fermentation pattern in propionic acid bacteria. Journal of General Microbiology 7I, 5I 5-524.

White, D. C., Bryant, M. P. \& Caldwell, D. R. (1962). Cytochrome-linked fermentation in Bacteroïdes ruminicola. Journal of Bacteriology 84, 822-828. 